Chalmers, J. (2017) Clarifying the law on assisted suicide? Ross v Lord Advocate. Edinburgh Law Review, 21(1), pp. 93-98.

(doi:10.3366/elr.2017.0391)

This is the author's final accepted version.

There may be differences between this version and the published version. You are advised to consult the publisher's version if you wish to cite from it.

http://eprints.gla.ac.uk/130144/

Deposited on: 17 October 2016

Enlighten - Research publications by members of the University of Glasgow http://eprints.gla.ac.uk 
This article has been accepted for publication by Edinburgh University Press in the Edinburgh Law Review, and is expected to appear in the January 2017 issue. The Review is available online at http://www.euppublishing.com/loi/elr.

\section{Clarifying the Law on Assisted Suicide? Ross v Lord Advocate}

Gordon Ross, who died in January 2016, ${ }^{1}$ was a retired television producer who prior to his death resided in a care home, living with diabetes, heart problems, Parkinson's disease and peripheral neuropathy. ${ }^{2}$ In Ross $v$ Lord Advocate, Lord Carloway outlined the dilemma which Mr Ross faced in the following terms: ${ }^{3}$

He anticipates that there will come a time when he will not wish to continue living, as he will find his infirmity and consequent dependence on others intolerable. He would require assistance to commit suicide because of his physical state. He is apprehensive that anyone who assisted him would be liable to prosecution. He considers that he may require to take action to end his life himself, sooner than he would otherwise wish to, in order to avoid living on in an undignified and distressing condition. This dilemma causes him uncertainty and anguish.

Mr Ross brought a petition for judicial review in the Court of Session, seeking inter alia a declarator that the Lord Advocate had breached article 8 of the ECHR by "failing to promulgate a policy identifying the facts and circumstances which he will take into account in deciding whether or not to authorise the prosecution in Scotland of a person who helps another person to commit suicide". Superficially, Mr Ross's case looked like the Scottish equivalent of $R$ (Purdy) $v D P P,{ }^{5}$ where Ms Purdy challenged the Director of Public Prosecution's failure to issue an equivalent policy in respect of England and Wales. But while Ms Purdy succeeded in her challenge, Mr Ross failed. Why?

\section{A. THE DIFFERENCES BETWEEN PURDY AND ROSS}

In Purdy, it was held that the possibility of a prosecution of Ms Purdy's husband, by constraining her decision on whether and how to end her life, could amount to an interference with her right to respect to private life under article 8(1) of the ECHR. As prosecution would be a matter of discretion, it was necessary for the scope of that discretion and the manner of

\footnotetext{
${ }^{1}$ L Buchan, "Tributes paid to right-to-die campaigner Gordon Ross", The Scotsman 13 January 2016.

${ }^{2}$ Ross v Lord Advocate [2016] CSIH 12, 2016 SCCR 176 at para 3. The court's judgment was issued in

February 2016. Lord Carloway, Lady Dorrian and Lord Drummond Young delivered separate opinions.

${ }^{3}$ Ibid.

${ }^{4}$ Ross v Lord Advocate [2015] CSOH 123, 2015 SLT 617 at para 6. All subsequent references to Ross are to the decision of the Inner House cited at $\mathrm{n} 2$.

5 [2009] UKHL 45, [2010] 1 AC 345. See J Chalmers, “Assisted suicide: jurisdiction and discretion" (2010) 14 EdinLR 295; J Rogers, "Prosecutorial policies, prosecutorial systems, and the Purdy litigation" [2010] Crim LR 543.
} 
its exercise to be clearly stated in order for any interference to be in accordance with the law, as required by article $8(2){ }^{6}$

The position of the Lord Advocate has consistently been to argue the requirement for an offence-specific policy identified in Purdy is contingent on particular features of English law and so has no applicability in Scotland. That can be seen both in the statement issued by the Lord Advocate shortly after Purdy, ${ }^{7}$ and in the arguments deployed in Ross itself.

There are two aspects to this argument, which might be described as empirical and doctrinal. The empirical aspect is that, in England and Wales, the need for offence-specific guidance had been very clearly demonstrated by the case of Daniel James, where the Director of Public Prosecutions admitted that he had been unable to derive much guidance from the Code for Crown Prosecutors (the English equivalent of the Scottish Prosecution Code) ${ }^{8}$ in deciding not to prosecute the parents of a 23-year-old man who had assisted him in his decision to travel to Switzerland and end his life at a clinic there. Given that admission, it was hardly open to the DPP to argue that the Code provided sufficient guidance on how prosecutors should deal with such cases.

By contrast, there was no directly equivalent case in Scotland. It was argued that, in four particular prosecutorial decisions, Crown Office had reached decisions which were inconsistent with stated policy. These arguments failed, with Lord Drummond Young observing that three of them turned on a conclusion that there was insufficient evidence for prosecution, in which case the question of prosecutorial discretion did not arise. Lord Drummond Young's dismissal of the first case, referred to as HM Advocate $v P B$, is rather more surprising and merits quoting in full: ${ }^{9}$

.... a family member who had been asked by a relative suffering from a degenerative illness to kill him and had done so by administering an overdose of medication and subsequently smothering him was charged with murder, and a plea to culpable homicide was offered by the defence and accepted. The facts available were sparse, but nothing appears to be significantly contrary to the statements of the Lord Advocate; the only issue of doubt is why a plea to culpable homicide was accepted, but no information is available about that.

This may be thought odd: the existence of a case in which the exercise of discretion could seemingly not be explained or justified in terms of the Prosecution Code might be considered good evidence that the Code was in some way inadequate. But no more was said about this, and Mr Ross's case therefore had to rest on a doctrinal claim: that Scots criminal law was sufficiently similar to English criminal law to give rise to the problem identified in Purdy.

This is a superficially difficult claim. The relevant offence in English law is that of complicity in another's suicide under section 2(1) of the Suicide Act 1961, ${ }^{10}$ which has no

\footnotetext{
${ }^{6}$ See Purdy at para 32 per Lord Hope of Craighead, citing Hasan and Chaush v Bulgaria (2000) 34 EHRR 1339 at para 84 .

${ }^{7}$ The text of this statement is reproduced at (2010) 14 Edin LR 12.

${ }^{8}$ The latest version of the English Code is Crown Prosecution Service, Code for Crown Prosecutors (2013). See also Crown Office and Procurator Fiscal Service, Prosecution Code (2001).

${ }^{9}$ Ross at para 77, emphasis added.

${ }^{10}$ Shortly after the decision in Purdy, the terms of this provision were amended with a redrafted offence as a result of s 59 of the Coroners and Justice Act 2009, but the change is not relevant for present purposes.
} 
direct equivalent in Scots law. However, if one person causes the death of another, Scots law can in principle hold them guilty of murder or culpable homicide. ${ }^{11}$ There is no reason why the difference in the label attached to the offence should avoid the problem identified in Purdy, particularly as the maximum penalty for the offence under section 2(1) is less than that for murder. ${ }^{12}$ However, if the extent to which the law of homicide can apply to assisted suicide is narrower than the extent of the section 2(1) offence, then it would be arguable that the Purdy problem is avoided. Is it?

\section{B. THE SCOPE OF THE CRIMINAL LAW}

In this context, two difficulties arise. First, does a person who supplies the means of suicide to another cause their death in law? Secondly, does a person who assists with the travel of another abroad to commit suicide commit an offence in Scotland? Ross offers, at first sight, some clarity in answering these questions.

As an aside, it might be thought surprising that any member of the Ross court was willing to make statements about the criminal law at all. In Law Hospital Trust v Lord Advocate, ${ }^{13}$ where the Court of Session was asked to grant a declarator that it would be lawful to cease to provide treatment to a patient in a persistent vegetative state, the court held that it was not open to it to pronounce on the scope of the criminal law. This would have created the anomaly of an issue of criminal law being potentially subject to appeal to the House of Lords (now, to the Supreme Court), and any declarator could not be binding on the High Court or Lord Advocate. These difficulties did not, however, arise directly in Ross, where there was no question of issuing a declarator setting out the scope of the criminal law. They do illustrate the limited formal value of observations on the scope of the criminal law made in Ross, but the practical reality is that statements made by senior judges on this topic will rightly be treated with respect. So what does Ross tell us?

\section{(1) Breaking the causal chain}

The issue of whether a supplier of drugs to a person can be said to have caused any injury which results from the person taking them has been a vexed one in Scots law for some time. ${ }^{14}$ In England, it has been held that a voluntary and informed decision to take a drug must break the causal chain. ${ }^{15}$ In contrast, the Scottish courts have most recently stated that such an act "will not necessarily" break the chain of causation, but without explaining what test is to be applied in determining whether or not the chain is broken. ${ }^{16}$

In Ross, Lord Carloway asserts that "[e]xactly where the line of causation falls to be drawn is a matter of fact and circumstance for determination in each individual case. That does not,

\footnotetext{
${ }^{11}$ See P R Ferguson, "Killing 'without getting into trouble’? Assisted suicide and Scots criminal law" (1998) 2 EdinLR 288.

${ }^{12} 14$ years' imprisonment (Suicide Act $1961 \mathrm{~s} 2(1 \mathrm{C})$ ), in contrast to the mandatory penalty of life imprisonment for murder (Criminal Procedure (Scotland) Act 1995 s 205(1)).

131996 JC 301. See H Lardy, "Euthanasia and euphemism" (1997) 1 EdinLR 227.

${ }^{14}$ At least since Khaliq v HM Advocate 1984 JC 23.

${ }^{15} R v$ Kennedy [2008] 1 AC 269.

${ }^{16}$ MacAngus v HM Advocate; Kane v HM Advocate [2009] HCJAC 8, 2009 SLT 137 at para 48.
} 
however, produce any uncertainty in the law."17 (Again, however, it remains unclear what test is to be applied in assessing the facts and circumstances.) He adds that: ${ }^{18}$

...the voluntary ingestion of a drug will normally break the causal chain. When an adult with full capacity freely and voluntarily consumes a drug with the intention of ending his life, it is this act which is the immediate and direct cause of death. It breaks the causal link...

No argument or authority is deployed in order to reach this conclusion. It does, however, offer a rather clearer statement of the law, at least in relation to one particular factual situation. There is, however, no such clear statement in Lady Dorrian's opinion - simply an acknowledgment that a settled intention to end one's life "may be an important consideration in a question of causation", ${ }^{19}$ while Lord Drummond Young's opinion does not touch on the issue.

\section{(2) Assisting with travel abroad to commit suicide}

This question is even more complex, because it is not clear how it is to be framed. There are two possible routes to concluding that a person who aids another to travel abroad in order to commit suicide commits no offence: either that they are not in law a cause of the death (for similar reasons to those discussed above) or that the Scottish courts would have no jurisdiction where the final act constituting the offence occurs abroad.

The second of these route is not discussed in Ross, and so the jurisdictional issue remains unclear. ${ }^{20}$ Lord Carloway, however, suggests that the first route is a conclusive answer to the question: "acts, including taking persons to places where they may commit, or seek assistance to commit, suicide, fall firmly on the other side of criminality". ${ }^{21}$ The sole authority cited in support is a paragraph in MacAngus and Kane where Lord Hamilton said only that such actions "do not necessarily" break the causal chain. ${ }^{22}$ Again, Lady Dorrian's comments on causation are more cautious, ${ }^{23}$ while Lord Drummond Young does not address the point.

\section{CONCLUSION}

In the aftermath of Ross, it was suggested that the observations of Lord Carloway significantly clarified the law on assisted suicide. ${ }^{24}$ In a formal sense, this is not strictly true. These are brief comments about the criminal law made in a civil case by a single judge. They

\footnotetext{
${ }^{17}$ Ross at para 29.

${ }^{18}$ Ross at para 30.

${ }^{19}$ Ross at para 61, emphasis added.

${ }^{20}$ The closest relevant authority, at least in the modern case law, may be Laird v HM Advocate 1985 JC 37, but this decision on cross-border fraud can hardly be said to provide a clear answer as to the jurisdictional question arising in the present context.

${ }^{21}$ Ross at para 31.

${ }^{22}$ MacAngus; Kane at para 42.

${ }^{23}$ Ross at paras 58-62.

${ }^{24}$ See A Tickell, "How a dying man brought clarity to the law", The Times, 25 February 2016 ("While prosecutors waffled and hedged, judges were crystal clear...")
} 
are not endorsed (although they are not dissented from) by the other judges who heard the case, and they could not bind the criminal courts even if they had been.

Such formalism would, however, be to miss the point. This is not an area in which there appears to be much appetite for law reform. Nor does it appear to be an area in which prosecutors are eager to bring prosecutions, although it is difficult to draw firm conclusions in this area in the absence of detailed information about cases which occur but are not investigated or are investigated but not prosecuted. Lord Carloway's observations may not be formally binding, but provide a sufficient basis for prosecutors to take no action in future cases where one person who has assisted another to end their own life. ${ }^{25}$ Scots law may be left in a state of uneasy equivocation about its stance on assisted suicide, but for all its flaws, uneasy equivocation may cause less distress and pain to those faced with the most difficult of ethical dilemmas than one of harsh clarity.

James Chalmers

University of Glasgow

${ }^{25}$ They do not, of course, provide a basis for inaction in a case such as HMAdvocate $v$ PB, discussed earlier in this note. 